\title{
Glyco- and Peptidomimetics from Three-Component Joullie-Ugi Coupling Show Selective Antiviral Activity
}

\author{
Timothy M. Chapman, ${ }^{\dagger, \ddagger}$ leuan G. Davies, ${ }^{\dagger}$ Baohua Gu, ${ }^{\S}$ Timothy M. Block,, David I. C. Scopes," \\ Philip A. Hay, ${ }^{\|, \perp}$ Stephen M. Courtney,,,$\perp$ Luke A. McNeill, ${ }^{\dagger}$ Christopher J. Schofield, ${ }^{\dagger}$ and \\ Benjamin G. Davis*, \\ Chemistry Research Laboratory, University of Oxford, Mansfield Road, Oxford U.K., OX1 3TA, Drexel Institute for \\ Biotechnology \& Virology Research, Drexel University, College of Medicine, 700 East Butler Avenue, \\ Doylestown, Pennsylvania 18901, and Oxford Glycosciences Ltd, The Forum, 86 Milton Park, \\ Abingdon, Oxfordshire U.K., OX14 4RY
}

Received October 6, 2004; E-mail: ben.davis@chem.ox.ac.uk

The hydroxylated pyrrolidine scaffold provides valuable sources not only of glycomimetics ${ }^{1}$ but also of hydroxyproline derivatives. ${ }^{2}$ With the aim of creating biodivergently targeted libraries, we have exemplified a multicomponent reaction (MCR) giving novel bisamide pyrrolidines accessed through a chlorination-elimination strategy. ${ }^{3}$ Previous studies have shown such imines to be efficient scaffolds for reaction with organometallic reagents. ${ }^{3}$ We demonstrate here that they are also highly effective components in MCRs that may be applied to library construction.

The mechanism proceeds via intermediates that are common to the Ugi reaction, ${ }^{4}$ a widely used reaction in library construction. ${ }^{5}$ However, the use of cyclic imine components in MCRs is rare: in 1989 Joullié demonstrated the role of a single cyanophenoxy dihydropyrrole. ${ }^{6,7}$ It is all the more surprising that such a "JoulliéUgi" process has not been applied to hydroxylated cyclic scaffolds as this would yield a ready route to compounds that could be considered as either azasugars or dihydroxyprolyl peptides. The motif thus formed would therefore potentially be effective in both carbohydrate processing (e.g., glycosidase) and/or peptide-processing (e.g., prolyl peptidase) inhibitors. ${ }^{1,2,8}$ Several important syntheses of dihydroxyproline modules have been reported; ${ }^{9}$ many highlight the difficulty, length, ${ }^{10}$ relatively low yields, ${ }^{11}$ and long reaction times ${ }^{11}$ of prolyl amide coupling. Improved access to coupled hydroxyprolines is desirable. We hereby report that entry to the Joullié-Ugi reaction through elimination followed by facile deprotection has allowed access to one of the most wide-ranging azasugar/dihydroxyprolyl libraries, ${ }^{12}$ which in turn has yielded potent inhibitors of two disease-associated targets, one based on inhibition of carbohydrate processing and one on peptide processing.

Erythritol 3 and threitol 4 imines, formed from treatment of $N$-chloramine precursors 1 and $\mathbf{2}$ (Scheme 1) with DBU established the unoptimized viability of reaction with $N$-acetyl glycine $\mathbf{v}$ and benzyl isocyanide D (Scheme 1), giving reasonable yields of elaborated bisamide (68 and 64\% yield over two steps from 1 and 2, respectively); excellent diastereoselectivity (de > 98\%) was observed for erythritol 6vD. ${ }^{13}$ Deprotection with TFA proceeded smoothly in $90 \%$ for erythritol 8vD and $62 \%$ for the 2,3-trans threitol species 9vD. Conditions for ready parallel handling were then established: isocyanides were removed in vacuo and acids were removed by base wash, and final treatment with TFA afforded pure deprotected product without recourse to chromatography.

University of Oxford.

\# Current address: Chemistry Dept., 80 St. George St., Toronto, Canada

$\S$ Drexel University.

"Oxford Glycosciences Ltd.

${ }^{\perp}$ Current address: Evotec OAI, 151 Milton Park, Abingdon, Oxon U.K., OX14 4SD.
Scheme 1. Joullié-Ugi MCRa

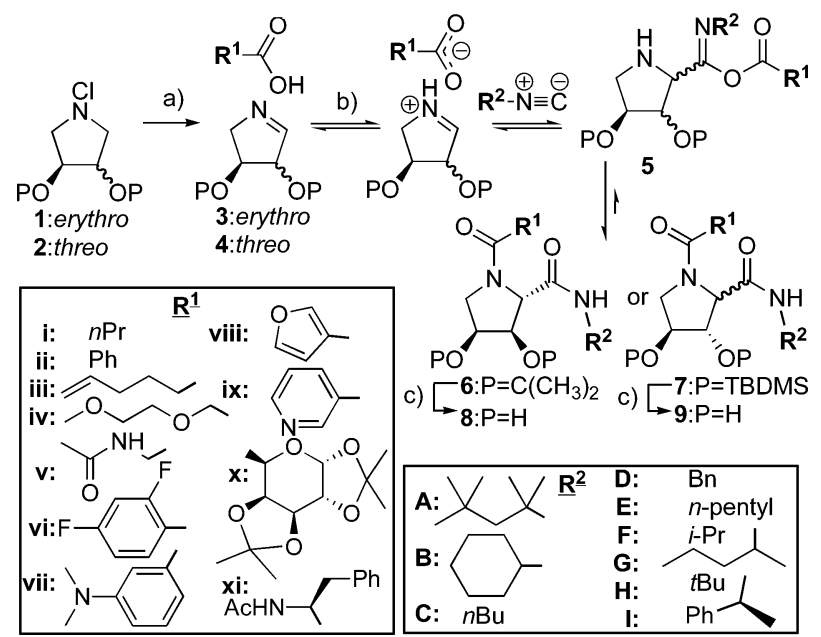
THF.

Carboxylic acids $\mathbf{i}-\mathbf{i x}$ and isocyanides $\mathbf{A}-\mathbf{H}$ (Scheme 1) were selected for a library. ${ }^{12}$ These included hydrophobic groups since they have been shown to enhance the activity of inhibitors of glycosidases, glucosylceramide synthase, and prolyl-processing enzymes. ${ }^{8,14}$ Test arrays probed efficiency. Reaction of $\mathbf{1}$ with $\mathrm{N}$-acetyl glycine $\mathbf{v}$ and isocyanides $\mathbf{A}-\mathbf{H}$ gave single diastereoisomers in total yields of $43-77 \% .^{15} \mathbf{1}$ plus acids $\mathbf{i}-\mathbf{i x}$ with isocyanide $\mathbf{C}$ gave 55-99\% yield also as single diastereomers. Similar studies on $\mathbf{2}$ gave similarly good to excellent yields (78$98 \%$ with $\mathbf{v}^{15,16}$ plus $\mathbf{A}-\mathbf{H}$ and $77-100 \%$ with $\mathbf{C}$ plus $\mathbf{i}-\mathbf{i x}$ as a 1:1 mixture of diastereoisomers). ${ }^{15,17}$ Deprotection of all adducts (TFA) proceeded quantitatively in most cases. ${ }^{15}$ Having established a good level of generality, the library was expanded to 132 deprotected members in total yields of $42-100 \%$ from erythritol $\mathrm{N}$-chloramine $\mathbf{1}$ and $77-100 \%$ from threitol $\mathrm{N}$-chloramine 2, all at $>90 \%$ purity as determined by LC-MS and ${ }^{1} \mathrm{H}$ NMR. ${ }^{15}$

More complex homochiral components were also tested, including representative biomolecule fragments. $(S)$-sec-Phenethyl isocyanide I and $N$-Ac-L-phenylalanine xi gave 51 and $59 \%$ yield and $>98 \% \mathrm{de}^{18}$ with viii and $\mathbf{E}$, respectively. Disappointingly, proline, deprotected glucuronic, and galacturonic acids gave little product. Protection of sugar hydroxyls is typical in successful MCRs, ${ }^{5,19}$ and gratifyingly, protected D-galacturonic acid $\mathbf{x}^{20}$ gave $44 \%$ overall yield, $>98 \%$ de $(\mathbf{1}+\mathbf{x}+\mathbf{E})$ of azadisaccharide mimic $\mathbf{9 x E}$.

Having readily generated an array of potential glyco- and peptidomimetics, we probed their activities against 15 different 


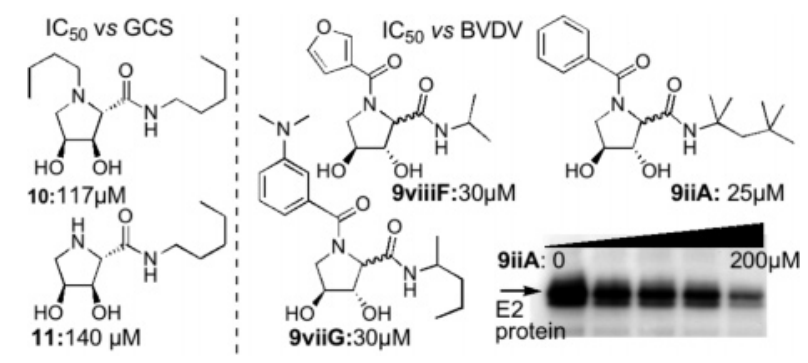

Figure 1. Identified inhibitors of glucosylceramide synthase, bovine viral diarrhoea virus, and anti-E2 Western assay of 9iiA-treated BVDV.

sugar- and peptide-based targets. To test glycomimicry, the library was screened against five human glycosidases, five non-mammalian glycosidases, and the glycosyltransferase glucosylceramide synthase (GCS), a Gaucher's disease target. ${ }^{21}$ The entire library showed little or no inhibition of glycosidases at $100 \mu \mathrm{M} .{ }^{22}$ This appears to be due to requirement for a basic endocyclic nitrogen atom. Gratifyingly, treatment of $\mathbf{9 i E}$ with 1.5 equiv of lithium aluminum hydride ${ }^{23}$ allowed the rarely performed chemoselective ${ }^{24}$ reduction of the tertiary amide in the presence of the secondary amide at C-1 and library elaboration; ${ }^{25} \mathbf{1 0}$ and $\mathbf{1 1}$ were successfully identified as GCS inhibitors with $\mathrm{IC}_{50} 117$ and $140 \mu \mathrm{M}$, respectively (Figure 1). Inhibitors of HIF hydroxylases are of current anti-ischemic interest, ${ }^{26}$ and elastases are implicated in, e.g., pancreatitis, rheumatoid arthritis, and emphysema. To test peptide mimicry, the library was screened against peptide-processing target enzymes that preferentially accept substrates that contain prolyl residues, FIH, ${ }^{27} \mathrm{PHD} 2,{ }^{28}$ and porcine pancreatic elastase, but showed only low inhibition. ${ }^{15}$

Finally, the library was tested in whole pathogen assays against hepatitis B virus (HBV) and bovine diarrhoea virus (BVDV), which is a primary model of human HCV. ${ }^{29,30}$ A specific pattern of potency against $\mathrm{BVDV}$ for aromatic $\mathrm{R}^{1}$ and branched $\mathrm{R}^{2}$ substituents emerged. IC $_{50}$ values of $25 \mu \mathrm{M}$ (9iiA) and $30 \mu \mathrm{M}$ (9viiG, 9viiiF, $\mathrm{MOI}=0.5$, Figure 1) compare very favorably with $N \mathrm{~N}-\mathrm{DNJ}$ (deoxynojirimycin), $10 \mu \mathrm{M}, \mathrm{MOI}=0.1$ and better than those for $N B-D N J(125 \mu \mathrm{M}, \mathrm{MOI}=0.1) .{ }^{31}$ Reduction of viral protein E2 level, lack of glycosidase, and HBV inhibition also indicated a novel, selective mechanism distinct from those of these previous imino sugars. ${ }^{31}$ We believe this to be the first example of a BVDV inhibiting azasugar that does not affect HBV. Excitingly, no significant toxicity was observed even at highest concentration $(300 \mu \mathrm{M})$.

In conclusion, a rarely constructed azasugar/dihydroxy prolyl array was assembled efficiently through three-component JoulliéUgi reaction accessed using chlorination-elimination methodology and allowed the identification of inhibitors of carbohydrate- and peptide-processing targets, including disease enzyme GCS and model viral pathogen BVDV.

Acknowledgment. We thank Dr. R. Donis, Nebraska, for the kind gift of BVDV to T.M.B. and the EPSRC, BBSRC, The Wellcome Trust, NIH (AI54764-01) and Oxford Glycosciences for support.

Supporting Information Available: Experimental procedures and characterization data for all library members and for biological testing. This material is available free of charge via the Internet at http:// pubs.acs.org.

\section{References}

(1) (a) Winchester, B.; Fleet, G. W. J. Glycobiology 1992, 2, 199. (b) Winchester, B.; al Daher, S.; Carpenter, N. C.; Cenci di Bello, I.: Choi, S. S.; Fairbanks, A. J.; Fleet, G. W. J. Biochem. J. 1993, 290, 743

(2) (a) Lázaro, A.; Garcia, L.; Correia, C. R. D. Tetrahedron Lett. 2003, 44 1553. (b) Chakraborty, T. K.; Srinivasu, P.; Kumar, S. K.; Kunwar, A. C. J. Org. Chem. 2002, 67, 2093.
(3) (a) Chapman, T. M.; Courtney, S.; Hay, P.; Davis, B. G. Chem. Eur. J. 2003, 9, 3397. (b) Davis, B. G.; Maughan, M. A. T.; Chapman, T. M.; Villard, R.; Courtney, S. Org. Lett. 2002, 4, 103.

(4) (a) Ugi, I.; Steinbrückner, C. Chem. Ber. 1961, 94, 734. (b) Ugi, I. Angew. Chem., Int. Ed. Engl. 1962, 1, 8.

(5) (a) Sutherlin, D. P.; Stark, T. M.; Hughes, R.; Armstrong, R. W. J. Org. Chem. 1996, 61, 8350. (b) Isenring, H. P.; Hofheinz, W. Synthesis 1981, 385. (c) Hoel, A. M. L.; Nielsen, J. Tetrahedron Lett. 1999, 40, 3941. (d) Liu, L.; Li, C. P.; Cochran, S.; Ferro, V. Bioorg. Med. Chem. Lett. 2004, 14, 2221. (e) Geday, S.; Van der Eycken, J.; Fulöp, F. Org. Lett. 2002, 4 , 1967.

(6) Bowers, M. M.; Carroll, P.; Joullié, M. M. J. Chem. Soc., Perkin Trans. $1 \mathbf{1 9 8 9}, 857$

(7) More recently, tetrahydropyridines have been used vs aldehyde/amine condensate. See: Maison, W.; Lützen, A.; Kosten, M.; Schlemminger I.; Westerhoff, O.; Martens, J. J. Chem. Soc., Perkin Trans. 1 1999, 3515.

(8) (a) Furneaux, R. H.; Limberg, G.; Tyler, P. C.; Schramm, V. L. Tetrahedron 1997, 53, 2915. (b) Evans, G. B.; Furneaux, R. H.; Hutchison, T. L.; Kesar, H. S.; Morris, P. E.; Schramm, V. L.; Tyler, P. C. J. Org. Chem. 2001, 66, 5723. (c) Lohse, A.; Jensen, K. B.; Lundgren, K.; Bols M. Bioorg. Med. Chem. 1999, 7, 1965. (d) Wright, P. A.; Wilmouth, R. C.; Clifton, I. J.; Schofield, C. J. Eur. J. Biochem. 2001, 268, 2969.

(9) (a) Taylor, C. M.; Weir, C. A. J. Org. Chem. 2000, 65, 1414. (b) Jenkins, C. L.; Bretscher, L. E.; Guzei, I. A.; Raines, R. T. J. Am. Chem. Soc. 2003, 125, 6422. (c) Kalaus, G.; Malkieh, N.; Kajtár-Peredy, M.; Brlik, J.; Szabó, L.; Szántay, C. J. Org. Chem. 1988, 53, 42.

(10) (a) Steger, M.; Hubschwerlen, C.; Schmid, G. Bioorg. Med. Chem. Lett. 2001, 11, 2537. (b) Taylor, C. M.; Barker, W. D.; Weir, C. A.; Park, J. H. J. Org. Chem. 2002, 67, 4466. (c) Weir, C. A.; Taylor, C. M. J. Org. Chem. 1999, 64, 1554. (d) Fujii, M.; Miura, T.; Kajimoto, T.; Ida, Y Synlett 2000, 1046.

(11) Typically no higher than $\sim 70 \%$ and up to 10 days. See ref 9 .

(12) Albeit modest in comparison to other compound libraries, this is a promising step for azasugars. For leading examples, see: (a) Saotome, C.; Wong, C.-H.; Kanie, O. Chem. Biol. 2001, 8, 1061 (27 member). (b) Wu, C.-Y.; Chang, C.-F.; Chen, J. S.-Y.; Wong, C.-H.; Lin, C.-H. Angew. Chem. Int Ed. 2003, 42, 4661 (60 members). (c) Gerber-Lemaire, S.; Popowycz, F.; Rodríguez-García, E.; Asenjo, A. T. C.; Robina, I.; Vogel, P. ChemBioChem. 2002, 5, 466 (96 member).

(13) Interestingly, little selectivity ( $\mathrm{dr} 1: 1$ ) was seen for threitol 7 $\mathbf{v D}$.

(14) (a) Butters, T. D.; van den Broek, L. A. G. M.; Fleet, G. W. J.; Krulle T. M.; Wormald, M. R.; Dwek, R. A.; Platt, F. M. Tetrahedron: Asymmetry 2000, 11, 113. (b) Fernandez, J. H.; Hayashi, M. A. F.; Camrgo, A. C. M.; Neshich, G. Biochem. Biophys. Res. Commun. 2003, 308, 219.

(15) See Supporting Information for further details

(16) The reaction with benzyl isocyanide gave an anomalous yield of $49 \%$.

(17) $\mathrm{N}$-Methylpyrrole-2-carboxylic acid gave no Ugi product.

(18) No efficiency difference for either of the two enantiomers of imine 3.

(19) Lockhoff, O. Angew. Chem., Int. Ed. 1998, 37, 3436.

(20) Godage, H. Y.; Fairbanks, A. J. Tetrahedron Lett. 2000, 41, 7589.

(21) Sawkar, A. R.; Cheng, W.-C.; Beutler, E.; Wong, C.-H.; Balch, W. E.; Kelly, J. W. Proc. Natl. Acad. Sci. U.S.A. 2002, 99, 15428.

(22) This was unexpected since imino sugars with hydrophobic substituent are inhibitors of GCS (see: Platt, F. M.; Neises, G. R.; Karlsson, G. B.; Dwek, R. A.; Butters, T. D. J. Biol. Chem. 1994, 269, 27108) and glycosidases (refs 3 and 8).

(23) Reduction with L-selectride or 9-BBN both proceeded sluggishly, even at reflux, and no trace of the reduction product could be detected.

(24) Soai, K.; Ookawa, A. J. Org. Chem. 1986, 51, 4000.

(25) Although selectivities for $\mathbf{1 0}$ vs $\mathbf{1 1}$ were poor, pleasingly and strikingly, no reduction of the secondary amide was detected.

(26) Hewitson, K.; McNeill, L.; Schofield, C. J. Curr. Pharm. Des. 2004, 10, 821.

(27) Factor inhibiting hypoxia-inducible factor, which catalyzes hydroxylation of VNAP motifs. See: (a) Hewitson, K. S.; McNeill, L. A.; Riordan, M. V.; Tian, Y. M.; Bullock, A. N.; Welford, R. W.; Elkins, J. M.; Oldham, N. J.; Battacharya, S.; Gleadle, J. M.; Ratcliffe, P. J.; Pugh, C. W.; Schofield, C. J. J. Biol. Chem. 2002, 277, 26351. (b) Lando, D.; Peet, D. J.; Whelan, D.; Gorman, J.; Whitelaw, M. Science 2002, 295, 858

(28) Isoform of the prolyl hydroxylase domain containing hydroxylases. See: (a) Jaakkola, P.; Mole, D. R.; Tian, Y.-M.; Wilson, M. I.; Gielbert, J.; Gaskell, S. J.; von Kriegsheim, A.; Hebestreit, H. F.; Mukherji, M.; Schofield, C. J.; Maxwell, P. H.; Pugh, C. W.; Ratcliffe, P. J. Science 2001, 292, 468. (b) Ivan, M.; Kondo, K.: Yang, H.; Kim, W.; Valiando, J.; Ohh, M.; Salic, A.; Asara, J. M.; Lane, W. S.; Kaelin, W. G., Jr. Science 2001, 292, 464. (c) Epstein, A. C. R.; Gleadle, J. M.; McNeill, L. A.; Hewitson, K. S.; O'Rourke, J.; Mole, D. R.; Mukherji, M.; Metzen, E.; Wilson, M. I.; Dhanda, A.; Tian, Y.-M.; Masson, N.; Hamilton, D. L.; Jaakola, P.; Barstead, R.; Hodgkin, J.; Maxwell, P. H.; Pugh, C. W. Schofield, C. J.: Ratcliffe, P. J. Cell 2001, 107, 43. (d) Schofield, C. J.; Ratcliffe, P. J. Nat. Rev. Mol. Cell. Biol. 2004, 5, 343.

(29) Zitzmann, N.; Mehta, A. S.; Carrouée, S.; Butters, T. D.; Platt, F. M. McCauley, J.; Blumberg, B.; Dwek, R. A.; Block, T. M. Proc. Natl. Acad. Sci. U.S.A. 1999, 96, 11878

(30) A surrogate in the absence of a suitable $\mathrm{HCV}$ system since, as Flaviviridae, both share protein homology and replication strategies. It also has severe effects upon infected herds, leading to an estimated economic loss of \$20 million per million calvings. See: Houe, H. Biologicals 2003, 31, 137.

(31) Durantel, D.; Branza-Nichita, N.; Carrouée-Durantel, S.; Butters, T. D. Dwek, R. A.; Zitzmann, N. J. Virol. 2001, 75, 8987.

JA043924L 